\title{
Psychological Profile and Sleep Quality of Patients with Temporomandibular Joint Dysfunction with or without Bruxism
}

\author{
Bruksizmi Olan ve Olmayan Temporomandibular Eklem Bozukluğu Hastaların \\ Psikolojik Profili ve Uyku Kalitesi
}

\author{
(1) Ömer Ekici
}

Afyonkarahisar Health Sciences University Faculty of Dentistry, Department of Oral and Maxillofacial Surgery, Afyonkarahisar, Turkey

\begin{abstract}
Objective: Bruxism is characterised by clenching or grinding of the teeth due to contraction of the masseter, temporalis and other jaw muscles. This study aimed to evaluate the psychological profile and sleep quality of patients with temporomandibular dysfunction (TMD) with or without bruxism.

Materials and Methods: The study was carried out in patients with TMD who were treated at the oral and maxillofacial surgery clinic of a faculty of dentistry. A total of 464 patients diagnosed with temporomandibular joint disorder according to the research diagnostic criteria for TMD were included in the study and divided into two groups based on presence or absence of bruxism. The State-trait Anxiety Inventory-T anxiety scale and Beck Depression scale were used to evaluate the psychological state of these patients. The quality of sleep was evaluated with Pittsburgh Sleep Quality index (PSQI). Data were analysed with the SPSS-20 statistical program.

Results: The frequency of bruxism was found to significantly alter in accordance with anxiety and depression levels $(p<0.005)$. The rates of bruxism were $58.3 \%, 70.1 \%$ and $79 \%$ in the group with the lowest, moderate and severe anxiety levels, respectively. Bruxism was observed in $72.9 \%, 78.5 \%$ and $100 \%$ of the patients in the mild, moderate and severe depression groups, respectively. Significant differences were observed in the sleep quality of patients with TMD with and without bruxism. It was observed that $68.6 \%$ of patients with TMD and bruxism had poor sleep quality, while only $58.6 \%$ of those without bruxism had poor sleep quality $(p<0.005)$. The scores for "sleep latency" and "sleep disturbances" were higher in the bruxism group as compared to nonbruxism group $(p<0.005)$. However, no significant difference was noted in the total PSQI scores for both groups $(p=0.145)$.

Conclusion: High anxiety and depression levels increased the incidence of bruxism. Patients with TMD and bruxism have poorer sleep quality than those with TMD but without bruxism.
\end{abstract}

Keywords: Sleep bruxism, psychological status, sleep quality, temporomandibular disorder
Öz

Amaç: Bruksizm masseter, temporalis ve diğer çene kaslarının kasılması nedeniyle dişlerin sıkılması veya öğütülmesi ile karakterizedir. Bu çalışmanın amacı, bruksizmi olan ve olmayan temporomandibular bozukluğu (TMD) olan hastaların psikolojik profilini ve uyku kalitesini değerlendirmektir.

Gereç ve Yöntem: Çalışma, bir diş hekimliği fakültesinin ağız ve çene-yüz cerrahisi kliniğine tedavi için gelen TMD hastaları üzerinde gerçekleştirildi. RDC/TMD'ye göre TME bozukluğu tanısı alan 464 hasta çalışmaya dahil edildi ve bruksizmi olan ve olmayan olmak üzere iki gruba ayrıldı. Psikolojik durumu değerlendirmek için STAI-T Anksiyete ölçeği ve Beck Depresyon ölçeği kullanıldı ve Pittsburgh Uyku Kalitesi indeksi (PSQI) ile uyku kalitesi değerlendirildi. Veriler SPSS-20 programı ile analiz edildi.

Bulgular: Bruksizm sıklığı anksiyete ve depresyon düzeylerine göre istatistiksel olarak anlamlı derecede farklılık gösterdi $(p<0,005)$. Bruksizm oranı en düşük anksiyete düzeyine sahip grupta $\% 58,3$, orta derecede anksiyete grubunda $\% 70,1$ ve şiddetli anksiyete grubunda $\% 79$ idi. Bruksizm hafif depresyon grubunun $\% 72,9^{\prime}$ unda, orta derece depresyon grubunun $\% 78,5^{\prime}$ inde ve şiddetli depresyonu olan grubun $\% 100$ 'ünde gözlendi. Bruksizmi olan ve olmayan TMD hastalarının uyku kalitesinde önemli farklılıklar gözlendi. Bruksizmi olan TMD hastalarının $\% 68,6^{\prime}$ sında, bruksizmi olmayanların \%58,6'sında düşük uyku kalitesi gözlendi $(p<0,005)$. Bruksizm hastalarının "uyku gecikmesi" ve "uyku bozuklukları" puanları bruksizmi olmayan gruptan daha yüksekti $(p<0,005)$. Ancak toplam PSQI skorları açısından her iki grup arasında anlamlı fark yoktu $(p=0,145)$.

Sonuç: Artan anksiyete ve depresyon düzeyleri hastalarda bruksizm insidansını artırdı. Bruksizmi olan TMD hastalarının, bruksizmi olmayanlara göre daha düşük uyku kalitesine sahip olduğu görüldü. Anahtar Kelimeler: Uyku bruksizmi, psikolojik durum, uyku kalitesi, temporomandibular bozukluk

Address for Correspondence/Yazışma Adresi: Ömer Ekici MD, Afyonkarahisar Health Sciences University Faculty of Dentistry, Department of Oral and Maxillofacial Surgery, Afyonkarahisar, Turkey Phone: +90 2722167900 E-mail: dromerekici@hotmail.com ORCID-ID: orcid.org/0000-0002-7902-9601 Received/Geliş Tarihi: 27.07.2020 Accepted/Kabul Tarihi: 14.01.2021

${ }^{\circ}$ Copyright 2021 by Turkish Sleep Medicine Society / Journal of Turkish Sleep Medicine published by Galenos Publishing House. 


\section{Introduction}

According to the American Academy of Orofacial Pain, temporomandibular disorders (TMDs) are described as a group of disorders including masticatory muscles, the temporomandibular joint (TMJ), and related structures (1). The most common signs and symptoms of temporomandibular disorder (TMD) are chronic pain, jaw muscle aches, restricted range of jaw movement, and TMJ noise (2). TMD has multifactorial etiology, involving genetic and behavioral causes, direct and indirect traumas, psychological factors, and postural and para-functional behaviors (3-5). The etiology of TMDs is considered to be complex and its natural course remains unclear. It is believed to be risk factors responsible for the onset or progression of the disease (1). One of these factors is sleep bruxism (SB), which is described as repetitive jaw-muscle activity characterized by clenching or grinding (6).

Bruxism is an involuntary and repeated jaw muscle movement characterized by tightening and/or grinding of teeth. Bruxism has two circular manifestations that can occur during sleep (called SB) or wakefulness [called awake bruxism (AB)] (6). AB is currently associated with psychosocial factors and/or motor disorders, although the etiology of $S B$ is not yet well understood $(7,8)$. $A B$ consists primarily of tooth clenching, though grinding is rarely seen. SB occurs more frequently with phasic (rhythmic), tonic (sustained), or mixed (both types) contractions of the jaw muscle (9). Several studies have indicated that SB is stimulated by the central nervous system, being correlated with microarousals and rhythmic masticatory muscle activity (RMMA) $(10,11)$.

$S B$ is regarded as a prevalent health issue and is present in $7.4 \%$ of the adult population (12). SB may lead to tooth wear (13), tooth and/or implants fractures (14), and headaches in the morning (15). It is also considered the predisposing and/ or main cause of the TMD (16). The relationship between bruxism and TMD, based on data, remains still controversial in literature due to the complexity etiological nature (17). The last research has demonstrated that the prevalence of SB can be substantially associated with high state and trait anxiety (18). It is probable that underlying anxiety and stress can aggravate bruxism along with more frequent sleep arousals. SB is one of the most common parasomnia encountered by adults (19). Repeated arousal during sleep, linked to increased anxiety and stress is known to be the key cause of poor sleep quality (SQ) (20). Psychosocial factors such as stress, anxiety and depression and poor SQ have also been reported in TMD patients (21-24). Therefore, the aim of this study is to examine the emotional states and SQ in TMD patients with and without SB and to reveal whether there is a difference between these two groups.

\section{Materials and Methods}

The study protocol was approved by the Ethics Committee of the Afyonkarahisar University of Health Sciences Turkey, Faculty of Medicine (2020/8-324). The study was conducted in full accordance with the World Medical Association Declaration of Helsinki. This cross-sectional evaluation involved 464 adults who sought treatment at the clinic of the oral and maxillofacial surgery, faculty of dentistry, Afyonkarahisar University of Health Sciences Turkey, Faculty of Medicine between 1 January 2020 and 30 June 2020. Written informed consents were obtained from all participants

The research diagnostic criteria for TMDs (25) was used to evaluate TMD patients. TMD patients over 18 years old who were diagnosed with TMD based on RDC/TMD diagnostic criteria were included in the study. Exclusion criteria consisted of psychiatric disability, neuromuscular disorders, malignancy, pregnancy, and current use of medication that could affect the central nervous system. A single calibrated oral and maxillofacial surgeon examined all patients and conducted all questionnaires and tests to patients. Four questionnaires were used in the current study.

\section{Assessment of Sleep Bruxism}

SB can be diagnosed through patient reports and clinical interviews, clinical examinations, intraoral appliances, or muscle activity recordings. According to the last international consensus, the diagnosis of bruxism made by self-report is classified as potential bruxism (6). According to American Academy of Sleep Medicine, SB was diagnosed if the participant reported or was aware of teeth-grinding sounds or teeth clenching during sleep. In addition, there must be one or more of the following signs: Abnormal tooth wear, temporary jaw muscle pain in the morning, muscle weakness at waking and hypertrophy of the masseter. The diagnosis of bruxism was made by a professional clinician on the basis of clinical diagnostic criteria for $S B$, as defined by the American Academy of Sleep Medicine (26).

\section{Assesment of Anxiety and Depression}

The state-trait anxiety inventory (STAI-T) was used to measure the level of anxiety. The STAl, developed by Spielberger and Gorsuch (27) consists of two questionnaires: State anxiety (STAI-S; momentary, depends on external conditions) and trait anxiety (STAI-T; characteristic of an individual, personality dependent). STAI-T scale was used for the study. The validity and reliability study of the Turkish version of the scale was made by Öner and LeCompte. (28). The scale consists of 20 items and responses range from 1-4. For questions with positive characters, the points are calculated by reversing. The total score obtained from the scale is between 20-80, high score indicates anxiety level is high.

Depression levels of the participants were measured by Beck depression inventory. The validity and reliability of the Turkish form of the scale were made by Hisli (29). This scale assesses the patient's psycho-emotional disposition towards the underlying world by identifying 21 issues in the patient's mental state over the past 24 hours. The questions were responded by participants using the four-point scale (0-3). By adding all the answers a total score has been obtained.

\section{Assessment of Sleep Quality}

The Turkish version of the Pittsburgh Sleep Quality index (PSQI) was used to assessed SQ. The PSQI consists of 19 questions and seven components: subjective $S Q$, sleep latency, sleep duration, 
habitual sleep efficiency, sleep disturbances, use of sleeping medications, and daytime dysfunction (26). Each portion is scored between 0 and 3; higher scores indicate the bad quality of sleep. A PSQI total score ranging from 0 to 21 points is obtained by adding the component points. Scores greater than five indicate poorer SQ.

\section{Statistical Analysis}

Statistical Package for Social Sciences (SPSS) for Windows software, version 20.0 (SPSS Inc., Chicago, IL, USA) was used for statistical analysis to evaluate the data. In the descriptive analysis, the number, percentage, mean, and standard deviation values were given. Independent samples t-test and One-Way ANOVA were used in cases with normal distribution, Mann-
Whitney $\mathrm{U}$ test and Kruskal-Wallis analysis test were used in cases without normal distribution. Chi-square analysis was used for categorical variables. Results were evaluated in a $95 \%$ confidence interval, at $p<0.05$ and $p<0.001$ significance levels.

\section{Results}

The sociodemographic characteristics of patients with TMJ dysfunction with and without bruxism were given in Table 1. Accordingly, the majority of the participants (82.8\%) were women. Approximately one-third of the participants (29.3\%) were in the $3^{\text {rd }}$ decade age range. $48 \%$ of the participants were married and $5.6 \%$ were divorced. $33.6 \%$ of the participants were high school graduates and $30.8 \%$ were middle school

\begin{tabular}{|c|c|c|c|c|c|c|c|}
\hline \multirow[b]{2}{*}{ Demographic data } & \multicolumn{2}{|l|}{ Total } & \multicolumn{2}{|c|}{ TMD with SB } & \multicolumn{2}{|c|}{ TMD without SB } & \multirow[b]{2}{*}{$p$} \\
\hline & $\mathbf{n}$ & $\%$ & $\mathbf{n}$ & $\%$ & $\mathrm{n}$ & $\%$ & \\
\hline \multicolumn{8}{|l|}{ Gender } \\
\hline Female & 384 & 82.8 & 307 & 79.9 & 77 & 20.1 & \multirow{2}{*}{$p=0.000^{\dagger}$} \\
\hline Male & 80 & 17.2 & 46 & 57.5 & 34 & 42.5 & \\
\hline \multicolumn{8}{|l|}{ Age } \\
\hline$<20$ years old & 103 & 22.2 & 75 & 72.8 & 28 & 27.2 & \multirow{5}{*}{$p=0.018$} \\
\hline 20-29 years old & 136 & 29.3 & 92 & 67.6 & 44 & 32.4 & \\
\hline 30-39 years old & 115 & 24.8 & 97 & 84.3 & 18 & 15.7 & \\
\hline 40-49 years old & 68 & 14.7 & 54 & 79.4 & 14 & 20.6 & \\
\hline 50 and over age & 42 & 9.1 & 35 & 83.3 & 7 & 16.7 & \\
\hline \multicolumn{8}{|l|}{ Marital status } \\
\hline Married & 223 & 48.1 & 173 & 77.6 & 50 & 22.4 & \multirow{3}{*}{$p=0.348$} \\
\hline Single & 215 & 46.3 & 158 & 73.5 & 57 & 26.5 & \\
\hline Divorced & 26 & 5.6 & 22 & 84.6 & 4 & 15.4 & \\
\hline \multicolumn{8}{|l|}{ Education status } \\
\hline Primary school & 122 & 26.3 & 85 & 69.7 & 37 & 30.3 & \multirow{5}{*}{$p=0.004$} \\
\hline Secondary school & 143 & 30.8 & 99 & 69.2 & 44 & 30.8 & \\
\hline High school & 156 & 33.6 & 132 & 84.6 & 24 & 15.4 & \\
\hline Faculty & 40 & 8.6 & 34 & 85 & 6 & 15 & \\
\hline Graduate & 3 & 0.6 & 3 & 100 & 0 & 0 & \\
\hline \multicolumn{8}{|l|}{ BMI } \\
\hline$<18.5 \mathrm{~kg} / \mathrm{m}^{2}$ (weak) & 30 & 6.5 & 23 & 76.7 & 7 & 23.3 & \multirow{4}{*}{$p=0.446$} \\
\hline $18.5-24.9 \mathrm{~kg} / \mathrm{m}^{2}$ (normal) & 243 & 52.4 & 178 & 73.3 & 65 & 26.7 & \\
\hline $25-29.9 \mathrm{~kg} / \mathrm{m}^{2}$ (overweight) & 144 & 31 & 116 & 80.6 & 28 & 19.4 & \\
\hline$>30 \mathrm{~kg} / \mathrm{m}^{2}$ (obese) & 47 & 10.1 & 36 & 76.6 & 11 & 23.4 & \\
\hline \multicolumn{8}{|l|}{ Occupation } \\
\hline Student & 151 & 32.5 & 108 & 71.5 & 43 & 28.5 & \multirow{7}{*}{$p=0.000^{\ddagger}$} \\
\hline Hausewife & 118 & 25.4 & 85 & 72 & 33 & 28 & \\
\hline Worker & 65 & 14 & 47 & 72.3 & 18 & 27.7 & \\
\hline Officer & 67 & 14.4 & 61 & 91 & 6 & 9 & \\
\hline Self-employment & 20 & 4.3 & 20 & 100 & 0 & 0 & \\
\hline Retired & 12 & 2.6 & 12 & 100 & 0 & 0 & \\
\hline Unemployed & 31 & 6.7 & 20 & 64.5 & 11 & 35.5 & \\
\hline Total & 464 & 100 & 353 & - & 111 & - & \\
\hline
\end{tabular}


graduates. According to the Body Mass index (BMI), $52.4 \%$ of the participants were at a normal weight. Most of the participants were students and housewives.

\section{Sociodemographic Features and Bruxism}

When bruxism status of patients was evaluated in terms of gender, $79.9 \%$ of women and $57.5 \%$ of men had bruxism. Accordingly, the frequency of bruxism was found significantly higher in women $(p<0.001)$. The frequency of bruxism varies significantly with age in the study $(p<0.005)$. According to this, bruxism was the most common in patients between the ages of 30-39, followed by patients aged 50 and over. Although bruxism was observed at the highest levels among divorced participants, there was no statistically significant difference in marital status $(p=0.348)$. As the education level increased, the incidence of bruxism increased and a significant difference occured in terms of education level $(p<0.005)$. The highest level of bruxism was seen in graduate, undergraduate and high school graduates, respectively. There was no significant difference in the frequency of bruxism in terms of BMI $(p=0.446)$. The frequency of bruxism showed a significant difference in terms of the occupation of the participants $(p<0.005)$. The rate of bruxism was higher among self-employed, retirees and civil servants.

\section{Psychological Status and Bruxism}

The psychological status of individuals has a great role in the emergence of bruxism. The anxiety and depression levels of TMJ patients with and without bruxism were evaluated and the differences between the two groups were examined. The anxiety level of the participants was evaluated with the STAI2 scale. Accordingly, mild anxiety was observed in 5.2\%, moderate anxiety in $20.9 \%$ and severe anxiety in $73.9 \%$ (Table 2 ). The frequency of bruxism was found to be statistically significantly changed according to anxiety levels $(p<0.005)$. The rate of bruxism was $58.3 \%$ in the group with the lowest anxiety level, $70.1 \%$ in the moderate anxiety group and $79 \%$ in the severe anxiety group. As the levels of anxiety increased, the rate of bruxism increased. In addition, when the STAI scale scores of TMJ patients with and without bruxism were examined, it was observed that the group with bruxism had a significantly higher STAI score than the group without bruxism $(p<0.005)$.

Depression levels of the participants were evaluated using the Beck Depression scale. In terms of depression levels, $43.5 \%$ of the participants had normal depression, $28.7 \%$ had mild depression, $23.1 \%$ had moderate depression and $4.7 \%$ had severe depression (Table 3 ). There was a significant relationship between the level of depression and the rate of bruxism $(p<0.005)$. Bruxism was observed in $72.9 \%$ of the mild depression group, $78.5 \%$ of the moderate depression group and $100 \%$ of the group with severe depression. As the level of depression increased, the rate of bruxism increased significantly.

\section{Sleep Quaility and Bruxism}

The SQ of TMD patients with and without bruxism was given in Table 4. Accordingly, while $31.4 \%$ of TMD patients with bruxism had good SQ, $68.6 \%$ of them had poor SQ. While $41.4 \%$ of those without bruxism had good SQ, $58.6 \%$ of them were found to have poor SQ. It was observed that the patients with bruxism had poor SQ compared to patients without bruxism $(p<0.005)$. SQ of patients with and without TME dysfunction with and without bruxism was assessed by the PSQI. The PSQI index total score of patients with bruxism was 6.64, while the total score of patients without bruxism was 6.10. Total PSQI scores in both groups showed poor sleep levels. However, there was no significant difference in terms of total PSQI scores of both groups $(p=0.145)$.

When patients with TMJ dysfunction with and without bruxism were examined in terms of the components that make up the PSQI SQ, only a significant difference was observed in the components of "sleep latency" and "sleep disorders" $(p<0.005)$. The mean scores of "sleep latency" and "sleep disturbances" in patients with bruxism were higher than the non-bruxism group. Patients with bruxism had poor SQ than the group without bruxism. There was no significant difference between the two groups in terms of other components of PSQI (Table 5).

\begin{tabular}{|c|c|c|c|c|c|c|}
\hline & & & \multicolumn{2}{|c|}{ TMD } & \multirow{2}{*}{ Total } & \multirow[b]{2}{*}{$p$} \\
\hline & & & With SB & Without SB & & \\
\hline \multirow{6}{*}{ STAI-T } & \multirow{2}{*}{$\begin{array}{l}\text { Mild } \\
\text { anxiety }\end{array}$} & \% within STAI & $58.3 \%$ & $41.7 \%$ & $100.0 \%$ & \multirow{7}{*}{$\mathrm{p}=0.022$} \\
\hline & & $\%$ of total & $3.0 \%$ & $2.2 \%$ & $5.2 \%$ & \\
\hline & $\begin{array}{l}\text { Moderate } \\
\text { anxiety }\end{array}$ & $\%$ of total & $14.7 \%$ & $6.2 \%$ & $20.9 \%$ & \\
\hline & \multirow{3}{*}{$\begin{array}{l}\text { Severe } \\
\text { anxiety }\end{array}$} & Number (n) & 271 & 72 & 343 & \\
\hline & & $\%$ within STAI & $79.0 \%$ & $21.0 \%$ & $100.0 \%$ & \\
\hline & & $\%$ of total & $58.4 \%$ & $15.5 \%$ & $73.9 \%$ & \\
\hline \multicolumn{2}{|l|}{ Total } & Number (n) & 353 & 111 & 464 & \\
\hline
\end{tabular}




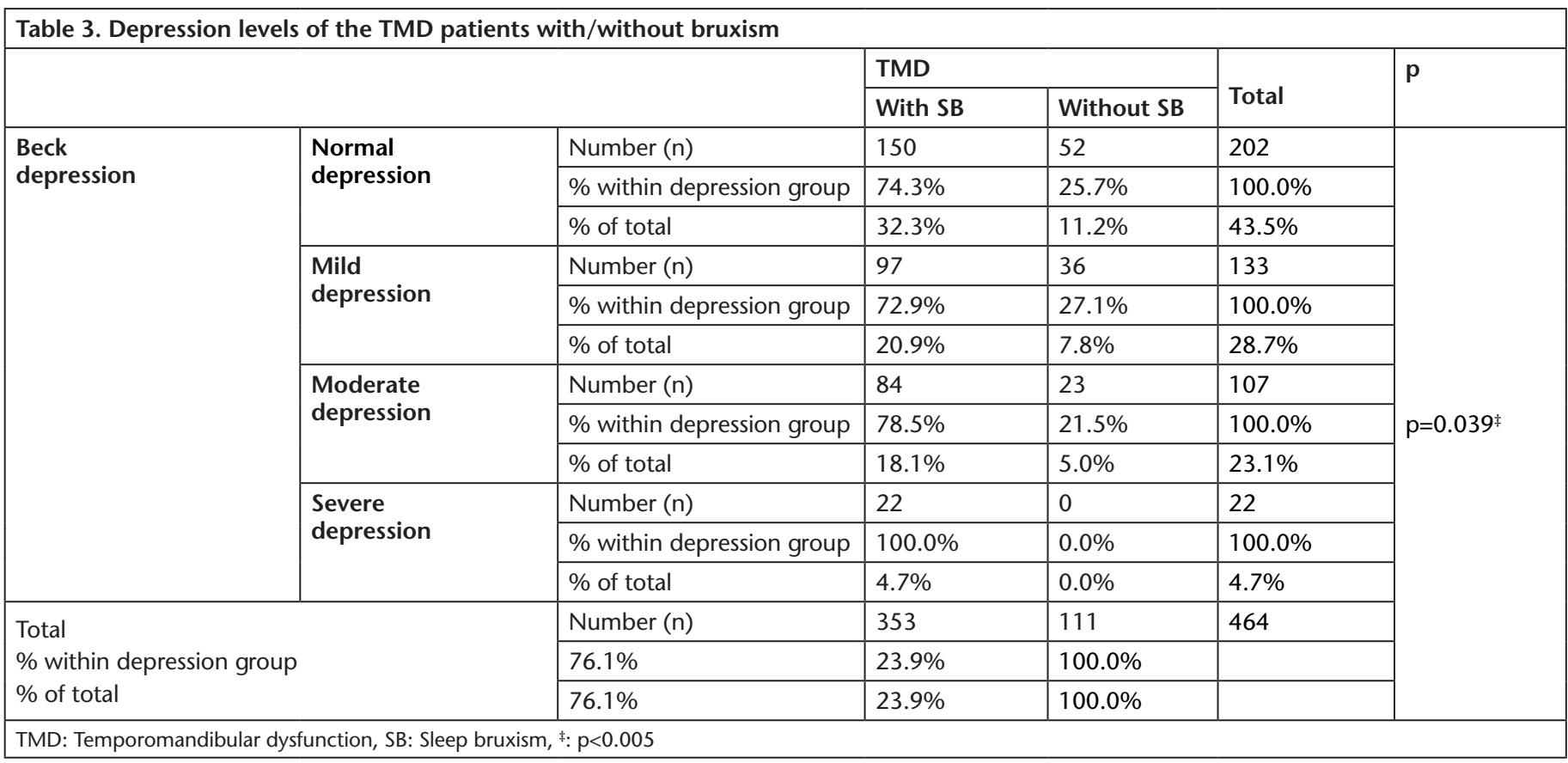

\begin{tabular}{|c|c|c|c|c|c|c|}
\hline & & & \multicolumn{2}{|c|}{ TMD } & \multirow[t]{2}{*}{ Total } & \multirow[t]{2}{*}{$p$} \\
\hline & & & With SB & Without SB & & \\
\hline \multirow{6}{*}{$\begin{array}{l}\text { Sleep } \\
\text { quality }\end{array}$} & \multirow{3}{*}{$\begin{array}{l}\text { Good } \\
\text { sleep }\end{array}$} & $\%$ within sleep quality & $70.7 \%$ & $29.3 \%$ & $100.0 \%$ & \multirow{8}{*}{$\mathrm{p}=0.035^{\ddagger}$} \\
\hline & & $\%$ within bruxism & $31.4 \%$ & $41.4 \%$ & $33.8 \%$ & \\
\hline & & $\%$ of total & $23.9 \%$ & $9.9 \%$ & $33.8 \%$ & \\
\hline & \multirow{3}{*}{$\begin{array}{l}\text { Poor } \\
\text { sleep }\end{array}$} & $\%$ within sleep quality & $78.8 \%$ & $21.2 \%$ & $100.0 \%$ & \\
\hline & & $\%$ within bruxism & $68.6 \%$ & $58.6 \%$ & $66.2 \%$ & \\
\hline & & $\%$ of total & $52.2 \%$ & $14.0 \%$ & $66.2 \%$ & \\
\hline \multirow{2}{*}{\multicolumn{2}{|c|}{ Total }} & Number (n) & 353 & 111 & 464 & \\
\hline & & $\%$ within sleep quality & $76.1 \%$ & $23.9 \%$ & $100.0 \%$ & \\
\hline
\end{tabular}

\begin{tabular}{|c|c|c|c|c|c|}
\hline \multirow[b]{2}{*}{ PSQI dimensions } & \multicolumn{2}{|c|}{ TMD with SB } & \multicolumn{2}{|c|}{ TMD without SB } & \multirow[b]{2}{*}{$\mathbf{p}$} \\
\hline & Mean & SD & Mean & SD & \\
\hline 1. Subjective sleep quality & 1.22 & 0.686 & 1.16 & 0.681 & $p=0.388$ \\
\hline 2. Sleep latency & 1.46 & 0.859 & 1.24 & 0.896 & $p=0.021^{*}$ \\
\hline 3. Sleep duration & 0.57 & 0.914 & 0.58 & 0.919 & $p=0.939$ \\
\hline 4. Sleep efficiency & 0.61 & 0.824 & 0.61 & 0.875 & $p=0.957$ \\
\hline 5. Sleep disturbances & 1.54 & 0.643 & 1.35 & 0.655 & $p=0.006^{\ddagger}$ \\
\hline 6. Use of sleep medication & 0.18 & 0.594 & 0.17 & 0.537 & $p=0.768$ \\
\hline 7. Daytime sleep dysfunction & 1.02 & 0.857 & 0.94 & 0.851 & $p=0.393$ \\
\hline PSQI global score & 6.64 & 3.417 & 6.10 & 3.267 & $p=0.145$ \\
\hline
\end{tabular}




\section{Discussion}

Bruxism is characterized by clenching or grinding the teeth because of the contraction of the masseter, temporalis, and other jaw muscles. Bruxism can lead to hypertrophy of the masticating muscles, loss of the tooth surface, fracture of restorations or teeth, hypersensitive or painful teeth, and loss of periodontal tissue. When polysomnography (PSG) sleep studies are conducted, SB and/or obstructive sleep apnea are often reported in TMD patients, but the associations with TMD for these two sleep-associated disorders are still poorly understood $(30,31)$. Despite the widely discussed concept of SB, etiology, prevalence, and relationship with TMD, many characteristics of this parafunction remain uncertain. Reports on the quality of sleep-related to bruxism are very few. Thus, this study aimed to compare psychological status and SQ in TMD patients with and without SB.

Recent research has demonstrated that SB frequency can be substantially associated with high-level state and trait anxiety, and those experiencing bruxism are twice as likely to experience extreme stress as non-bruxers $(18,20)$. The rate of bruxism was $58.3 \%$ in the group with the mild anxiety level, $70.1 \%$ in the moderate anxiety group and $79 \%$ in the severe anxiety group. Similarly, bruxism was observed in $72.9 \%$ of the mild depression group, $78.5 \%$ of the moderate depression group and $100 \%$ of the group with severe depression. These findings reveal that the frequency of bruxism is associated with anxiety and depression levels, and as the level of anxiety and depression increases, the frequency of bruxism increases.

Self-reported SQ was also evaluated in patients with SB, a condition that for many decades has been considered an etiological, sustaining and/or exacerbating factor for chronic myofascial TMD (32). The average sleep bruxer PSQI scores ranged from 6.08 to 10.8 , which indicates a low SQ in SB patients $(33,34)$. In the study of Câmara-Souza et al. (35), total PSQI score of the group with bruxism was 7.07 and poor sleep was reported in $80 \%$ of those with bruxism. Dias et al. (36) reported that $75.6 \%$ of bruxers were poor sleepers, whatever the form of bruxism. In our study, poor sleep observed in $68.6 \%$ of TMD patients with bruxism while $58.6 \%$ of TMD patients without bruxism. The group with bruxism had significantly poor SQ than the group without bruxism. Similar to the literature, in this study, the PSQI index total score of bruxism patients was found to be 6.64 , while the total score of patients without bruxism was 6.10. In our study, the reason for the high PSQI score of the group without bruxism can be explained by the fact that this group consists of TMD patients instead of completely healthy controls. Sleep disorders that also coexist with psychological distress have also been shown to be a risk factor for TMD $(21,22)$. Up to $90 \%$ of patients with TMD usually experience poor SQ (23). Up to 70 percent of patients with TMD meet at least one criterion for a sleep disorder and 43 percent meet two or more criteria (24). However, these study findings are important to show that TMD patients with bruxism have lower SQ than those without bruxism. This could be explained by the non-physiological RMMA which occurs with a higher intensity and frequency mostly companied by masseter muscle activity particularly in bruxers (37). This makes the sleep non-restorative and may cause tiredness and/or muscle pain at awakening $(15,38)$.

In our study, the "sleep latency" and "sleep disorders" components of TMD patients with bruxism were the two components affected by bruxism. There was no significant difference between the two groups in the other components of the PSQI index. In the PSG study of Palinkas et al. (38), similar to our results, higher sleep latency scores were observed in those with bruxism than those without bruxism. Another study has shown that the main areas affected by bruxism are subjective SQ and sleep disturbance (35). SB has been shown to be part of a complex central nervous system arousal response that occurs during sleep depth changes and is often followed by body movements, elevated heart rate, and respiratory changes $(39,40)$. These parameters affect the discharge of chemical mediators that stimulate the release of catecholamine, changing the initiation and maintenance of wakefulness and sleep (41). Additionally, alterations in sleep habits may worsen pain in SB patients (42), which directly affects SQ.

\section{Study Limitations}

The study had some limitations. The study included patients receiving TMD therapy and the results do not represent the general population. Laboratory sleep evaluation is needed to establish a definitive diagnosis of $S B$, but it is costly and inaccessible for large samples. The quality of sleep was evaluated with a subjective sleep questionnaire instead of PSG. The strengths of our study are that it was conducted in the large TMD sample group and it was the diagnosis TMD after the RDC/TMD diagnostic criteria, which are accepted as the gold standard (25).

\section{Conclusion}

The results of this study revealed that patients with bruxism have higher levels of anxiety and depression and poor SQ than those without bruxism. SB may be related to negative poor SQ of adults. Considering that bruxers are highly sensitive to psychological stres, and that psychophysiological insomnia is characterized by stress response, this could explain the loss of quality of sleep in bruxers.

\section{Acknowledgements}

The author would like to thank the temporomandibular disorder patients participating in this study. The author states that there is no conflict of interest.

Ethics Committee Approval: The questionnaire and methodology for this study was approved by the Human Research Ethics committee of the Afyonkarahisar University of Health Sciences Turkey, Faculty of Medicine (2020/8-324).

Informed Consent: Informed consent was obtained from all study participants.

Peer-review: Internally peer-reviewed.

Financial Disclosure: The author declared that this study received no financial support. 


\section{References}

1. Orofacial pain: guidelines for assessment, diagnosis, and management / I University of Toronto Libraries. Last Accessed Date: 30.04.2020. Available from: https://search.library.utoronto.ca/ details?9126690. Accessed April 30, 2020.

2. Miettinen O, Lahti S, Sipilä K. Psychosocial aspects of temporomandibular disorders and oral health-related quality-of-life. Acta Odontol Scand 2012;70:331-6.

3. Gavish A, Halachmi M, Winocur E, Gazit E. Oral habits and their association with signs and symptoms of temporomandibular disorders in adolescent girls. J Oral Rehabil 2000;27:22-32.

4. Monteiro DR, Zuim PRJ, Pesqueira AA, Ribeiro P do P, Garcia AR. Relationship between anxiety and chronic orofacial pain of temporomandibular disorder in a group of university students. J Prosthodont Res 2011;55:154-8.

5. Gameiro GH, da Silva Andrade A, Nouer DF, Ferraz de Arruda Veiga MC. How may stressful experiences contribute to the development of temporomandibular disorders? Clin Oral Investig 2006;10:261-8.

6. Lobbezoo F, Ahlberg J, Raphael KG, Wetselaar P, Glaros AG, Kato T, Santiago V, Winocur E, De Laat A, De Leeuw R, Koyano K, Lavigne G), Svensson P, Manfredini D. International consensus on the assessment of bruxism: Report of a work in progress. J Oral Rehabil 2018;45:837-44.

7. Kato T, Dal-Fabbro C, Lavigne G). Current knowledge on awake and sleep bruxism: Overview. Alpha Omegan 2003;96:24-32.

8. Manfredini D, Lobbezoo F. Role of psychosocial factors in the etiology of bruxism. J Orofac Pain 2009;23:153-66.

9. Lavigne GJ, Montplaisir JY. Restless legs syndrome and sleep bruxism: Prevalence and association among canadians. Sleep 1994;17:739-43.

10. Lavigne G], Kato T, Kolta A, Sessle BJ. Neurobiologicalmechanisms involved in sleep bruxism. Crit Rev Oral Biol Med 2003;14:30-46.

11. Lavigne G], Huynh N, Kato T, Okura K, Adachi K, Yao D, Sessle B. Genesis of sleep bruxism: Motor and autonomic-cardiac interactions. Arch Oral Biol 2007;52:381-4.

12. Maluly M, Andersen ML, Dal-Fabbro C, Garbuio S, Bittencourt L, de Siqueira JTT, Tufik S. Polysomnographic study of the prevalence of sleep bruxism in a population Sample. J Dent Res 2013;92(Suppl 7):S97-103.

13. (PDF) Tooth wear in young subjects: A discriminator between sleep bruxers and controls? Last Accessed Date: 01.05.2020. Available from: https://www.researchgate.net/publication/26701947_Tooth_ Wear_in_Young_Subjects_A_Discriminator_Between_Sleep_Bruxers_ and_Controls.

14. Manfredini D, Poggio CE, Lobbezoo F. Is bruxism a risk factor for dental Implants? A systematic review of the literature. Clin Implant Dent Relat Res 2014;16:460-9.

15. Lavigne G, Palla S. Transient morning headache Recognizing the role of sleep bruxism and sleep-disordered breathing. J Am Dent Assoc 2010;141:297-9.

16. Sierwald I, John MT, Schierz O, Hirsch C, Sagheri D, Jost-Brinkmann PG, Reissmann DR. Association of temporomandibular disorder pain with awake and sleep bruxism in adults. J Orofac Orthop 2015;76:305-17.

17. Manfredini D, Lobbezoo F. Relationship between bruxism and temporomandibular disorders: A systematic review of literature from 1998 to 2008. Oral Surg Oral Med Oral Pathol Oral Radiol Endod 2010;109:e26-50. doi:10.1016/j.tripleo.2010.02.013

18. Manfredini D, Arreghini A, Lombardo L, Visentin A, Cerea S, Castroflorio T, Siciliani G. Assessment of anxiety and coping features in bruxers: A portable electromyographic and electrocardiographic study. J Oral Facial Pain Headache 2016;30:249-54.
19. Ohayon MM, Li KK, Guilleminault C. Risk factors for sleep bruxism in the general population. Chest 2001;119:53-61.

20. Ahlberg J, Lobbezoo F, Ahlberg K, Manfredini D, Hublin C, Sinisalo J, Könönen M, Savolainen A. Self-reported bruxism mirrors anxiety and stress in adults. Med Oral Patol Oral Cir Bucal 2013;18:e7-11. doi:10.4317/medoral.18232

21. Smith MT, Wickwire EM, Grace EG, Edwards RR, Buenaver LF, Peterson $S$, Klick B, Haythornthwaite JA. Sleep disorders and their association with laboratory pain sensitivity in temporomandibular joint disorder. Sleep 2009;32:779-90.

22. Selaimen CMP, Jeronymo JCM, Brilhante DP, Grossi ML. Sleep and depression as risk indicators for temporomandibular disorders in a cross-cultural perspective: a case-control study. Int J Prosthodont 2006;19:154-61.

23. Yatani H, Studts ], Cordova M, Carlson CR, Okeson JP. Comparison of sleep quality and clinical and psychologic characteristics in patients with temporomandibular disorders. J Orofac Pain 2002;16:221-8.

24. Riley JL, Benson MB, Gremillion HA, Myers CD, Robinson ME, Smith Jr CL, Waxenberg LB. Sleep Disturbance in Orofacial Pain Patients: PainRelated or Emotional Distress? Cranio 2001;19:106-13.

25. Dworkin SF, LeResche L. Research diagnostic criteria for temporomandibular disorders: review, criteria, examinations and specifications, critique. J Craniomandib Disord 1992;6:301-55.

26. The international classification of sleep disorders : diagnostic \& coding manual. (Book, 2005) [WorldCat.org]. LastAccessed Date: 04.05.2020. Available from: https://www.worldcat.org/title/internationalclassification-of-sleep-disorders-diagnostic-coding-manual/ oclc/67281425.

27. Spielberger CD, Gorsuch RL LR. Manual for the state-trait anxiety Inventory ("self-evaluation questionnaire"). Palo Alto, CA: Consulting Psychologists Press; 1970.

28. Öner N, LeCompte A. State-Trait Anxiety Inventory Handbook (Istanbul Boğaziçi University, 1983) [WorldCat.org]. Last Accessed Date: 25.07.2020. Available from: https://www.worldcat.org/title/ durumluk-surekli-kayg-envanteri-el-kitab/oclc/81840585.

29. Hisli N. Beck depression inventory (BDI). 1989;23:3-13. Available from: https://toad.halileksi.net/olcek/beck-depresyon-envanteri.

30. Sanders AE, Essick GK, Fillingim R, Knott C, Ohrbach R, Greenspan JD, Diatchenko L, Maixner W, Dubner R, Bair E, Miller VE, Slade GD. Sleep apnea symptoms and risk of temporomandibular disorder: OPPERA cohort. J Dent Res 2013;92(Suppl 7):70S-7S.

31. Dubrovsky B, Raphael KG, Lavigne GJ, Janal MN, Sirois DA, Wigren PE, Nemelivsky LV, Klausner JJ, Krieger AC. Polysomnographic investigation of sleep and respiratory parameters in women with temporomandibular pain disorders. I Clin Sleep Med 2014;10:195-201.

32. Klasser GD, Greene CS, Lavigne GJ. Oral appliances and the management of sleep bruxism in adults: a century of clinical applications and search for mechanisms. Int J Prosthodont 2010;23:453-62.

33. Câmara-Souza MB, Figueredo OMC, Rodrigues Garcia RCM. Masticatory function and oral stereognosis in bruxers. Cranio - J Craniomandib Pract 2019;37:285-9.

34. Jokovic A, Locker D, Guyatt G. What do children's global ratings of oral health and well-being measure? Community Dent Oral Epidemiol 2005;33:205-11.

35. Câmara-Souza MB, de Figueredo OMC, Rodrigues Garcia RCM. Association of sleep bruxism with oral health-related quality of life and sleep quality. Clin Oral Investig 2019;23:245-51.

36. Dias GM, Bonato LL, Guimarães JP, Silva JNN, Ferreira LA, Grossmann E, Carvalho ACP. A study of the association between sleep 
bruxism, low quality of sleep, and degenerative changes of the temporomandibular joint. J Craniofac Surg 2015;26:2347-50.

37. Lavigne G], Kato T, Kolta A, Sessle BJ. Neurobiologicalmechanisms involved in sleep bruxism. Crit Rev Oral Biol Med 2003;14:30-46.

38. Palinkas M, Semprini M, Filho JE, de Luca Canto G, Regalo $I H$, Bataglion C, Rodrigues LAM, Siéssere S, Regalo SCH. Nocturnal sleep architecture is altered by sleep bruxism. Arch Oral Biol 2017;81:56-60.

39. Kato T, Montplaisir JY, Guitard F, Sessle BJ, Lund JP, Lavigne GJ. Evidence that experimentally induced sleep bruxism is a consequence of transient arousal. J Dent Res 2003;82:284-8.
40. Huynh N, Kato T, Rompré PH, Okura K, Saber M, Lanfranchi PA, Montplaisir JY, Lavigne GJ. Sleep bruxism is associated to microarousals and an increase in cardiac sympathetic activity. J Sleep Res 2006;15:339-46.

41. Carra MC, Huynh N, Lavigne G. Sleep bruxism: A comprehensive overview for the dental clinician interested in sleep medicine. Dent Clin North Am 2012;56:387-413.

42. Smith MT, Perlis ML, Smith MS, Giles DE, Carmody TP. Sleep quality and presleep arousal in chronic pain. J Behav Med 2000;23:1-13. 